\title{
ANALISIS KEMAMPUAN MENULIS KARANGAN NARASI DENGAN TEMA PERISTIWA DALAM KEHIDUPAN PADA MUATAN BAHASA INDONESIA
}

\author{
Simun Ardianto \\ SDN Pasinggangan, Banyumas, Indonesia \\ simunardianto@yahoo.co.id
}

\begin{abstract}
The research was aimed to (1) observe the students' skill in writing narrative text, (2) find the mistakes in standard Indonesian language of the narrative text on the topic of Life Phenomenon in Indonesian Subject of fifth graders Elementary School. The method applied was quantitative and qualitative, in a form of descriptive by collecting data using test and documentation. The data were obtained from the narrative text of the fifth graders' students SD N 1 Pasinggangan consisted of 31 students. The research showed that most of the students could compose narrative correctly with the mean score of 76, which mean in "good category". However, there were some mistakes about misspelling or mistake in grammar (252 from 139 collected data). The mistakes were spelling 33.33\%, punctuation $22.27 \%$, word decoding $5.16 \%$, mistyping $30.95 \%$, and grammar 3,56\% such as prefix, suffix, konfix, and infix $0.40 \%$.
\end{abstract}

Keywords: composing, narrative text, misspelling, grammar mistake

\begin{abstract}
Abstrak. Penelitian ini bertujuan untuk (1) mengetahui kemampuan menulis karangan narasi siswa (2) mengetahui bentuk-bentuk kesalahan penggunaan Ejaan Yang Disempurnakan dan tata bahasa pada hasil karangan narasi siswa dengan tema Peristiwa dalam Kehidupan pada muatan Bahasa Indonesia kelas V di Sekolah Dasar. Metode yang digunakan adalah kuantitatif dan kualitatif yang bersifat deskriptif dengan pengumpulan data menggunakan teknik tes dan studi dokumenter. Data dalam penelitian ini adalah hasil karangan narasi siswa dengan sumber data penelitian adalah siswa kelas $\mathrm{V}$ di SD Negeri 1 Pasinggangan yang berjumlah 31 siswa. Hasil penelitian menunjukkan bahwa bahwa secara umum siswa kelas V di SD Negeri 1 Pasinggangan telah mampu membuat karangan narasi sesuai dengan tema yang ditentukan yang dibuktikan dengan capaian nilai rata-rata kelas sebesar 76 dengan kategori BAIK, tetapi masih ditemukan kesalahan penulisan ejaan dan tata bahasa sebanyak 252 kesalahan dari 139 data kesalahan yang telah dikumpulkan. Kesalahan dalam penulisan ejaan meliputi kesalahan penggunaan huruf sebanyak 33,33\%, kesalahan pemakaian tanda baca sebanyak $22,27 \%$, kesalahan pemenggalan kata sebanyak 5,16\%, dan kesalahan penulisan kata sebanyak 30,95 $\%$ serta kesalahan tata bahasa sebanyak 3,56 \% meliputi kesalahan penulisan prefiks, konfiks, dan kesalahan penulisan partikel sebanyak $0,40 \%$.
\end{abstract}

Kata Kunci: menulis, karangan narasi, kesalahan ejaan, kesalahan tata bahasa

\section{PENDAHULUAN}

Aktivitas menulis tidak pernah lepas dalam kehidupan sehari-hari di berbagai bidang. Kenyataannya, dalam kehidupan sekarang masih ditemukan bentuk kesalahan dalam kegiatan menulis. Kesalahan tersebut antara lain kesalahan penggunaan Ejaan Yang Disempurnakan (EYD) dan tata bahasa dalam aktivitas menulis oleh para pelajar. Siswa melakukan kesalahan penggunaan EYD dan tata bahasa yang bervariasi. Contoh nyata dalam kehidupan sehari-hari misalnya peneliti sering menjumpai pelajar yang melakukan kesalahan dalam praktek menulis seperti membuat naskah pidato, membuat naskah pembawa acara pengajian, dan membuat karangan yang penulisannya tidak sesuai dengan aturan EYD dan tata bahasa. Contoh lain dalam kehidupan misalnya pelajar atau seseorang masih melakukan kesalahan penulisan 
dalam membuat surat. Mereka terkesan masih bingung sehingga kurang tepat dalam membuat surat izin maupun surat lamaran pekerjaan yang sesuai dengan aturan EYD dan tata bahasa.

Fenomena serupa tidak hanya ditemukan pada siswa Sekolah Dasar (SD) tetapi ditemukan juga pada siswa dengan jenjang pendidikan yang lebih tinggi seperti oleh siswa Sekolah Menengah Pertama (SMP), Sekolah Menengah Atas (SMA) bahkan oleh mahasiswa di tingkat perguruan tinggi. Pembelajaran penggunaan EYD dan tata bahasa tersebut sudah diajarkan pada saat pembelajaran menulis di sekolah dasar. Sekolah dasar sebagai pelaksana pendidikan dasar merupakan sarana yang secara umum mengajarkan keterampilan dasar berbahasa kepada siswa.

Proses pembelajaran berbahasa di sekolah dasar mencakup empat aspek yaitu menyimak, berbicara, membaca, dan menulis. Meskipun menulis merupakan aspek yang diajarkan pada tahap akhir, tetapi bukan berarti tidak penting. Kegiatan menulis justru merupakan tahap yang lebih rumit jika dibandingkan dengan aspek berbahasa lainnya. Siswa yang pandai berbicara belum tentu dapat menulis dengan baik dan benar. Begitu juga dengan siswa yang pandai berbicara dan membaca juga belum tentu dapat menulis dengan baik dan benar.

Keterampilan menulis merupakan aspek berbahasa yang sangat penting. Menulis juga harus menerapkan aturan tata tulis yaitu EYD dan tata bahasa yang berlaku. Penggunaan EYD dan tata bahasa yang baik dan benar dalam menulis sangat penting karena berfungsi untuk memperjelas gagasan dan pesan yang ditulis oleh penulis itu sendiri. Apabila penggunaan ejaan dan tata bahasa yang digunakan tidak tepat dalam menulis, maka tulisan akan sulit dipahami oleh pembaca.
Hal tersebut dikarenakan penyampaian gagasan yang disampaikan melalui tulisan berbeda dengan penyampaian gagasan yang disampaikan secara langsung.
Akhadiah
dkk
(1999:

mengemukakan bahwa penggunaan bahasa Indonesia secara baik dan benar dalam tulis menulis, harus pula ditunjang oleh penerapan peraturan ejaan yang berlaku dalam bahasa Indonesia, yaitu Ejaan Yang Disempurnakan. Penerapan ejaan dan tata tulis dalam menulis sangat penting karena berfungsi untuk memperjelas gagasan dan pesan yang ditulis oleh penulis. Hal ini dikarenakan gagasan yang disampaikan melalui tulisan berbeda dengan gagasan yang disampaikan melalui lisan dan tatap muka. Gagasan yang disampaikan melalui lisan dan tatap muka akan lebih mudah dipahami karena dalam berbahasa lisan mengandung unsur-unsur yang tidak bisa diadakan dalam bahasa tulis seperti faktor gerak-gerik, mimik bibir, intonasi, irama, jeda serta unsur-unsur non bahasa lainnya yang ikut memperlancar. Penerapan ejaan dan tata tulis dalam menulis berperan untuk menggantikan unsur non bahasa tersebut dalam menyampaikan gagasan secara tertulis. Penerapan ejaan yang tidak sesuai dalam penulisan juga dapat menimbulkan sebuah kata atau kalimat yang ambigu atau bahkan tidak bermakna sama sekali.

Kegiatan pembelajaran menulis di sekolah dasar yang diajarkan di kelas rendah maupun di kelas tinggi adalah kegiatan menulis karangan. Pada kegiatan menulis karangan, selain siswa harus dapat menuangkan ide dan gagasan dalam bentuk tulisan, mereka juga harus cermat dan tepat dalam menggunakan ejaan dan tata bahasa. Pembelajaran penggunaan ejaan dan tata bahasa dilakukan sejak berada di kelas rendah sebagai dasar dan pedoman bagi siswa dalam mengikuti pembelajaran menulis yang lebih rumit di kelas tinggi. 
Siswa kelas tinggi seperti kelas V (lima) idealnya sudah mampu menulis karangan yang baik dan benar dengan menerapkan EYD dan tata bahasa yang sesuai.

Tenaga pendidik seharusnya mengetahui kemampuan menulis dan bentuk-bentuk kesalahan dalam menulis karangan termasuk penggunaan EYD dan tata bahasa oleh siswa. Hal tersebut sebagai upaya untuk meningkatkan kulaitas kemampuan siswa dan mencegah kesalahan yang dilakukan oleh siswa. Upaya tersebut dapat membantu siswa dalam kehidupan nyata di masyarakat, khususnya dalam kegiatan yang berhubungan dengan aktivitas menulis diberbagai bidang. Hal ini penting karena kesalahan penggunaan EYD dan tata bahasa pada kegiatan menulis dapat terus berlanjut apabila tidak mendapatkan perhatian yang serius sejak dini.

Penelitian ini menganalisis kemampuan menulis karangan narasi siswa kelas V sekolah dasar. Proses analisis menghasilkan gambaran yang rinci dan jelas mengenai kemampuan menulis karangan narasi siswa dan bentuk-bentuk kesalahan penulisan ejaan dan tata bahasa pada hasil karangan siswa. Hasil penelitian ini diharapkan dapat menjadi sumbangan pemikiran yang dapat digunakan sebagai acuan dalam meningkatkan kualitas pendidikan, khususnya meningkatkan keterampilan berbahasa dalam aspek menulis sehingga dapat menjadi solusi bagi guru untuk meningkatkan kemampuan siswanya dalam menulis karangan yang sesuai dengan aturan EYD dan tata bahasa. Pentingnya mengetahui kemampuan menulis pada siswa, maka peneliti mengadakan penelitian dengan judul "Analisis Kemampuan Menulis Karangan Narasi dengan Tema Peristiwa dalam Kehidupan pada Muatan Bahasa Indonesia Siswa Kelas V Sekolah Dasar”.

\section{METODOLOGI PENELITIAN}

Metode yang akan digunakan dalam penelitian ini adalah kuantitatif dan kualitatif yang bersifat deskriptif. Creswell (2013:22) lebih rinci menyebutkan bahwa metode campuran (kuantitatif dan kulaitatif) merupakan metode yang menggunakan prosedur-prosedur dimana didalamnya peneliti berusaha menggabungkan atau memperluas penemuan-penemuannya yang diperoleh dari satu metode dengan penemuan dari metode yang lain. Pengertian deskriptif menurut ahli merupakan suatu bentuk penelitian yang paling dasar yang ditujukan untuk mendeskripsikan atau menggambarkan fenomena-fenom ada baik fenomena alamiah rekayasa manusia, Sukmadinata (2

Penelitian ini mengambil data darı hasil tes kegiatan menulis siswa yaitu nilai rata-rata kelas dalam menulis karangan narasi. Dokumen yang berupa hasil karangan narasi siswa kelas V SD Negeri 01 Pasinggangan, selanjutnya akan diidentifikasi untuk keperluan menganalisis bentuk-bentuk kesalahan penulisan ejaan dan tata bahasa pada hasil karangan narasi siswa. Data yang terkumpul selanjutnya dideskripsikan secara jelas sesuai dengan karakteristik kesalahan. Tahap terakhir dalam penelitian ini ialah membuat kesimpulan yang didasarkan pada deskripsi data sebelumnya.

Penelitian telah dilakukan di Sekolah Dasar Negeri 1 Pasinggangan. Sekolah tersebut berada dibawah pengawasan 57 Banyumas dan beralamat di Jalan ‥uyu Pasinggangan-Binangun Kecamatan Banyumas Kabupaten Banyumas Kode Pos 53192. Sekolah merupakan tempat observasi mata kuliah Keterampian Membaca dan Menulis pada semester 3, sehingga menjadi pertimbangan sebagai tempat penelitian. 


\section{Data dan Sumber Data}

Data dalam penelitian ini adalah hasil karangan narasi siswa. Sumber data dalam penelitian ini adalah seluruh siswa kelas $\mathrm{V}$ di SD Negeri 1 Pasinggangan yang berjumlah 31 siswa.Teknik yang digunakan dalam proses pengumpulan data penelitian menggunakan teknik tes dan studi dokumenter.

Tes yang digunakan adalah perintah mengerjakan menulis karangan narasi dengan tema yang telah ditentukan yaitu pengalaman siswa yang berkaitan dengan peranan air dalam kehidupan. Siswa mengerjakan menulis karangan narasi selanjutnya setelah selesai mengerjakan hasilnya dikumpulkan kepada peneliti untuk dianalisis.

Dokumen yang dianalisis ialah hasil pekerjaan siswa setelah menyelesaikan karangan narasi. Melalui studi dokumenter tersebut diperoleh data kesalahan siswa yang selanjutnya akan dianalisis dan dibahas dalam uraian deskriptif sesuai prosedur yang telah direncanakan.

Melalui kedua teknik tersebut akan diperoleh data mengenai kemampuan

\begin{tabular}{|c|c|c|l|}
\hline $\begin{array}{c}\text { Interval persentase tingkat } \\
\text { penguasaan }\end{array}$ & \multicolumn{2}{|c|}{ Nilai ubahan skala empat } & \multirow{2}{*}{ Keterangan } \\
\cline { 2 - 3 } & $1-4$ & D-A & \\
\hline $86-100$ & 4 & A & Baik Sekali \\
\hline $76-85$ & 3 & B & Baik \\
\hline $56-75$ & 2 & C & Cukup \\
\hline $10-55$ & 1 & D & Kurang \\
\hline
\end{tabular}

Untuk menganalisis bentuk-bentuk kesalahan Ejaan dan Tata bahasa, maka digunakan studi dokumenter. Dokumen berupa hasil karangan narasi dianalisis berdasarkan Ejaan Yang Disempurnakan yang berlaku dalam peraturan tata tulis di Indonesia menurut Departemen Pendidikan

Dari kedua teknik analisis data di atas maka kemampuan menulis karangan narasi dan bentuk-bentuk kesalahan penulisan menulis karangan narasi siswa yang berupa data nilai dalam angka-angka yang dihasilkan dari penskoran kriteria penulisan karangan serta dokumen berupa hasil menulis karangan narasi sehingga dari kedua teknik pengumpulan diperoleh data mengenai kemampuan siswa dalam menulis hasil karangan narasi dan bentukbentuk kesalahan siswa.

\section{Analisis Data}

Setelah data dikumpukan, maka selanjutnya adalah menganalisis data melalui data tes dan data studi dokumenter. Setelah dilakukan penskoran sesuai dengan kriteria menulis karangan, maka untuk mengetahui kemampuan menulis karangan narasi siswa digunakan penghitungan data tes. Setelah ditemukan nilai akhir maka dapat dihitung rata-rata dengan rumus jumlah semua skor dibagi jumlah subjek, Nurgiyantoro (2001 326). Nilai ubahan menurut Nurgiyantoro (2013: 253) menyebutkan penentuan kriteria dengan penghitungan presentase untuk skala empat sebagai berikut: 


\section{HASIL DAN PEMBAHASAN}

Pembahasan memberikan gambaran mengenai kemampuan menulis karangan narasi dan bentuk-bentuk kesalahan siswa sesuai dengan hasil karangan narasi yang telah dikerjakan. Kemampuan siswa didasarkan pada hasil perhitungan rata-rata nilai siswa melalui pedoman penskoran yang disesuaikan dengan kriteria menulis karangan narasi sehingga diperoleh angka-angka berupa nilai siswa. Analisis selanjutnya yaitu mendeskripsikan bentuk-bentuk kesalahan ejaan dan tata bahasa yang diperoleh dari studi domuneter yang berupa hasil karangan narasi siswa yang telah dilakukan penilaian. Pembahasan mengenai kemampuan menulis karangan narasi dan deskriptif kesalahan siswa akan diuraiakan lebih rinci sebagai berikut:

\section{A. Kemampuan Siswa Menulis Karangan Narasi}

Kemampuan menulis karangan narasi siswa diperoleh dari hasil penskoran penilaian karangan meliputi beberapa kriteria penskoran yaitu kualitas dan ruang lingkup isi, organisasi dan penyajian isi, gaya dan bentuk bahasa, dan mekanik. Pedoman penskoran penilaian menulis karangan narasi menurut Nurgiyantoro (dalam Iskandarwassid 2008: 250) tersebut dilakukan berdasarkan hasil pekerjaan siswa dalam menyelesaikan karangan yang kemudian diubah menjadi angka-angka yang selanjutnya diolah menjadi sebuah nilai akhir Arifin (2011: 229) yang menunjukkan kemampuan siswa dalam menulis karangan narasi seperti pada tabel pemerolehan skor disajikan pada Lampiran. Hasil penilaian pada tabel di atas menunjukkan bahwa capaian nilai rata-rata kelas menunjukkan kemampuan menulis karangan narasi siswa termasuk dalam katogori BAIK dengan pemerolehan nilai rata-rata 76 dengan indikator interval presentase penguasaan kisaran antara 7685 yang didasarkan pada pedoman penghitungan presentase kemampuan siswa. Nilai tertinggi dalam penilaian menulis karangan narasi adalah 83 sedangkan nilai terendah 58. Berdasrkan hasil penilaian di atas dapat diketahui bahwa siswa kelas $\mathrm{V}$ sudah mampu menulis karangan narasi sesuai dengan tema yang telah ditentukan meskipun masih ditemukan beberapa bentuk kesalahan penulisan

A. Bentuk-Bentuk Kesalahan Ejaan dan Tata Bahasa

Bentuk kesalahan penulisan yang tidak sesuai dengan aturan ejaan dan tata bahasa peneliti temukan dalam karangan narasi siswa. Kesalahan penulisan siswa tersebut bervariasi seperti kesalahan penulisan huruf kapital, penulisan diftong, penulisan tanda baca, kesalahan pemenggalan kata dan sebagainya. Peneliti meringkas data hasil analisis kedalam tabel untuk memudahkan pemahaman terhadap kesalahan tersebut. Apabila hasil analisis data disajikan dalam bentuk persentase, maka hasilnya adalah sebagai berikut: 
Tabel 1.

Persentase Bentuk-Bentuk Kesalahan

Penulisan Ejaan dan Tata Bahasa pada Hasil Karangan Narasi Siswa

\begin{tabular}{|c|c|c|c|c|}
\hline No & \multicolumn{2}{|c|}{ Jenis Kesalahan } & \multirow{2}{*}{$\begin{array}{c}\text { Jumlah } \\
84\end{array}$} & $\begin{array}{c}\text { Persentase } \\
(\%)\end{array}$ \\
\hline \multirow[t]{16}{*}{1.} & \multirow{16}{*}{$\begin{array}{l}\text { Kesalahan } \\
\text { Penulisan } \\
\text { Ketidaksesuaian } \\
\text { Penggunaan EYD }\end{array}$} & 1. Penulisan Huruf & & 33,33 \\
\hline & & a. Huruf Kapital & 76 & 30,16 \\
\hline & & b. Huruf Diftong & 5 & 1,99 \\
\hline & & c. Gab. Huruf Konsonan & 3 & 1,19 \\
\hline & & 2. Tanda Baca & 67 & 26,59 \\
\hline & & a. Tanda Baca Titik & 17 & 6,75 \\
\hline & & b. Tanda Baca Koma & 43 & 17,06 \\
\hline & & c. Tanda Hubung & 4 & 1,59 \\
\hline & & d. Tanda Petik & 3 & 1,19 \\
\hline & & 3. Pemenggalan kata & 13 & 5,16 \\
\hline & & 4. Penulisan Kata & 78 & 30,95 \\
\hline & & a. Kata Dasar & 12 & 4,76 \\
\hline & & b. Kata depan & 41 & 16,27 \\
\hline & & c. Kata ganti & 16 & 6,35 \\
\hline & & d. Angka dan bilangan & 7 & 2,78 \\
\hline & & e. Singkatan \& Akronim & 2 & 0,79 \\
\hline \multirow[t]{6}{*}{2.} & \multirow{5}{*}{$\begin{array}{l}\text { Kesalahan } \\
\text { Penulisan } \\
\text { Ketidaksesuaian } \\
\text { Penggunaan Tata } \\
\text { Bahasa }\end{array}$} & 1. Afiksasi & 9 & 3,56 \\
\hline & & a. Penulisan Prefiks & 7 & 2,78 \\
\hline & & b. Penulisan Sufiks & 1 & 0,40 \\
\hline & & c. Penulisan Konfiks & 1 & 0,40 \\
\hline & & 2. Penulisan Partikel & 1 & 0,40 \\
\hline & \multicolumn{2}{|l|}{ Jumlah Kesalahan } & 252 & \\
\hline
\end{tabular}

Berdasarkan tabel persentase di atas, jumlah kesalahan penulisan ejaan dan tata bahasa sebanyak 252 butir meliputi kesalahan penggunaan huruf kapital, diftong, gabungan huruf konsonan, pemenggalan kata, penulisan kata dasar, penulisan kata depan $d i$ - dan $k e-$, penulisan kata ganti ku-, kau- dan -nya, angka dan bilangan serta penulisan singkatan dan akronim. Kesalahan penulisan tata bahasa meliputi kesalahan penulisan prefiks, konfiks, sufiks, dan partikel.

Jenis kesalahan yang dilakukan oleh siswa ternyata bervariasi sehingga upaya untuk meningkatkan kemampuan menulis siswa perlu ditingkatkan. Kecermatan siswa dalam menulis juga menjadi kunci dalam proses menulis tersebut, hal ini dikarenakan menulis memerlukan kecermatan sehingga jangan sampai lupa terhadap aturan penulisan. Kemampuan berbahasa khususnya pada muatan Bahasa Indonesia jangan terlalu menekankan hanya kepada pengetahuan umum tetapi harus dituangkan dalam praktek sehingga akan selaras dengan penerapan aspek berbahasa.

\section{PENUTUP}

\section{A. Simpulan}

Berdasarkan data yang telah dikumpulkan dan dilakukan pembahasan, dapat ditarik kesimpulan sebagai berikut:

1. Siswa kelas V SD Negeri 1 Pasinggangan secara umum telah mampu menulis karangan narasi sesuai dengan tema yang telah ditentukan yang dibuktikan dengan 
nilai rata-rata kelas yang mencapai 76 dengan kategori BAIK dengan nilai terendah 58 dan tertinggi 83. Kriteria penskoran pada penilaian karangan narasi meliputi empat aspek keriteria yaitu: kualitas dan ruang lingkup isi (kesesuaian pemilihan judul dan kesesuaian isi dengan judul karangan), organisasi dan penyajian isi (tata tulis dan alur paragraf dan pengmbangan kalimat menjadi paragraf narasi), aspek gaya dan bentuk bahasa (penulisan kata pemilihan kata), dan aspek mekanik (penulisan huruf dan kapitalisasi, penulisan tanda baca, kerapihan dan kebersihan).

2. Bentuk-bentuk kesalahan penulisan ejaan dan tanda baca pada hasil karangan siswa sebanyak 252 kesalahan penulisan dari 139 data kesalahan yang telah diklasifikasikan sesuai kategori pembahasa. Presentase kesalahan tersebut yaitu kesalahan penggunaan huruf sebanyak 33,33\%, kesalahan pemakaian tanda baca sebanyak 22,27 \%, kesalahan pemenggalan kata sebanyak 5,16\%, dan kesalahan penulisan kata sebanyak $30,95 \%$. Benuk kesalahan tata bahasa bidang afiksasi sebanyak 3,56\% meliputi kesalahan penulisan prefiks, konfiks, dan kesalahan penulisan partikel sebanyak 0,40\%.

\section{B. Saran}

Berdasarkan hasil penelitian dan simpulan, peneliti memberikan saran sebagai berikut:

1. Guru sebaiknya memberikan pemahaman kepada siswa tentang pentingnya memperhatikan penulisan yang baik dan benar dengan memberikan contoh berbagai penulisan yang salah dan contoh penulisan yang benar serta memberikan penjelasan dan arahan dari dampak menulis sesuai contoh tersebut.

2. Pekerjaan siswa sebaiknya dikoreksi dengan memberikan tanda khusus yang jelas pada poin-poin kesalahannya kemudian hasilnya diserahkan kembali kepada siswa supaya siswa mengetahui kesalahannya.

3. Guru sebaiknya memberikan penekanan kepada siswa tentang aspek berbahasa khususnya penggunaan ejaan dan tata bahasa pada setiap aspek mata pelajaran dengan memberikan tanggapan kepada siswa baik secara langsung maupun dalam bentuk catatan sehingga kesalahan siswa pada aspek menulis selalu mendapatkan perhatian dan koreksi.

4. Siswa sebaiknya diberi praktek menulis yang lebih banyak yang dipadukan dengan kegiatan seperti perlombaan untuk melatih kecermatan siswa dalam menulis sehingga siswa akan terbiasa menulis yang baik dan benar.

5. Guru sebaiknya sering mengingatkan kepada siswa supaya cermat dan hatihati pada saat kegiatan menulis terutama dalam penggunaan ejaan dan tata bahasa untuk menghindari kesalahan penulisan.

6. Siswa harus cermat dalam penulisan ejaan dan tata bahasa untuk mengindari kesalahan penulisan dalam kegiatan menulis.

\section{DAFTAR PUSTAKA}

Akhadiah, Sabarti, dkk. 1995. Pembinaan Kemampuan Menulis Bahasa Indonesia. Jakarta: Erlangga.

Arifin, Z. 2011. Evaluasi Pembelajaran. Bandung: Remaja Rosdakarya.

Arikunto. 2002. Prosedur Penelitian Suatu Pendekatan Praktek. Jakarta: PT Asdi Mahasatya.

Creswell, John W. 2013. Research and Design (Pendekatan Kualitatif, kuantitatif dan mixed).Yogyakarta: Pustaka Pelajar

Departemen Pendidikan dan Kebudayaan. 2012. Pedoman Umum Ejaan Bahasa Indonesia Yang Disempurnakan dan Pedoman Umum Pembentukan Istilah. Surabaya: Palito Media 
Iskandarwassid. 2009. Strategi Pembelajaran Bahasa. Bandung: PT Remaja Rosdakarya.

Nurgiyantoro, Burhan. 2001. Penilaian dalam Pengajaran Bahasa dan Sastra. Yogyakarta: BPFE Yogyakarta

. (2013). Penilaian Pembelajaran Bahasa Berbasis Kompetensi. Yogyakarta: BPFE Yogyakarta.
Putrayasa, Ida Bagus. 2010. Kalimat Efektif (Diksi, Struktur dan Logika). Bandung: P.T. Refika Aditama.

Sumadinata. Nana Syaodih. 2010. Metode Penelitian Pendidikan. Bandung: PT. Remaja Rosdakarya. 


\section{Lampiran 1}

Bentuk-Bentuk Kesalahan

Penulisan Ejaan dan Tata Bahasa pada Hasil Karangan Narasi Siswa

\begin{tabular}{|c|c|c|c|c|}
\hline No & \multicolumn{2}{|c|}{ Jenis Kesalahan } & Jumlah & $\begin{array}{c}\text { Persentase } \\
(\%)\end{array}$ \\
\hline \multirow[t]{16}{*}{1.} & \multirow{16}{*}{$\begin{array}{l}\text { Kesalahan Penulisan } \\
\text { Ketidaksesuaian } \\
\text { Penggunaan EYD }\end{array}$} & 1. Penulisan Huruf & & \\
\hline & & a. Huruf Kapital & & \\
\hline & & b. Huruf Diftong & & \\
\hline & & c. Gab. Huruf Konsonan & & \\
\hline & & 2. Tanda Baca & & \\
\hline & & a. Tanda Baca Titik & & \\
\hline & & b. Tanda Baca Koma & & \\
\hline & & c. Tanda Hubung & & \\
\hline & & d. Tanda Petik & & \\
\hline & & 3. $\quad$ Pemenggalan kata & & \\
\hline & & 4. Penulisan Kata & & \\
\hline & & a. Kata Dasar & & \\
\hline & & b. Kata depan & & \\
\hline & & c. Kata ganti & & \\
\hline & & d. Angka dan bilangan & & \\
\hline & & e. Singkatan dan Akronim & & \\
\hline \multirow[t]{6}{*}{2.} & \multirow{5}{*}{$\begin{array}{l}\text { Kesalahan Penulisan } \\
\text { Ketidaksesuaian } \\
\text { Penggunaan Tata } \\
\text { Bahasa }\end{array}$} & 1. Afiksasi & & \\
\hline & & a. Penulisan Prefiks & & \\
\hline & & b. Penulisan Sufiks & & \\
\hline & & c. Penulisan Konfiks & & \\
\hline & & 2. Penulisan Partikel & & \\
\hline & \multicolumn{2}{|l|}{ Jumlah Kesalahan } & & \\
\hline
\end{tabular}




\section{Lampiran 2.}

\begin{tabular}{|c|c|c|c|c|c|c|c|c|c|c|c|c|}
\hline \multicolumn{13}{|c|}{ Pemerolehan Skor Siswa dalam Menulis Karangan } \\
\hline \multirow{3}{*}{ No } & \multirow{3}{*}{ Nama } & \multicolumn{8}{|c|}{ Pemerolehan Skor } & \multirow{3}{*}{ 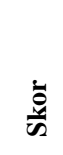 } & \multirow{3}{*}{$\frac{\tilde{\pi}}{\bar{z}}$} & \multirow{3}{*}{ Kriteria } \\
\hline & & \multicolumn{2}{|c|}{$\mathbf{A}$} & \multicolumn{2}{|c|}{ B } & \multirow{2}{*}{$\begin{array}{c}\mathbf{C} \\
\mathrm{C}\end{array}$} & \multicolumn{3}{|c|}{ D } & & & \\
\hline & & A1 & A2 & B1 & B2 & & D1 & $\mathrm{D} 2$ & D3 & & & \\
\hline 1 & Awaludin & 3 & 2 & 1 & 2 & 2 & 1 & 1 & 2 & 14 & 58 & Cukup \\
\hline 2 & Yusuf Maulana & 3 & 1 & 2 & 2 & 3 & 2 & 1 & 2 & 16 & 67 & Cukup \\
\hline 3 & Aditya C. P. & 3 & 2 & 3 & 2 & 3 & 2 & 2 & 3 & 20 & 83 & Baik \\
\hline 4 & Avia Nur. C. & 3 & 2 & 3 & 1 & 3 & 3 & 3 & 2 & 20 & 83 & Baik \\
\hline 5 & Bagus Dwi O. & 3 & 2 & 3 & 2 & 2 & 2 & 2 & 2 & 18 & 75 & Cukup \\
\hline 6 & Cinta Putri A. & 3 & 3 & 3 & 2 & 3 & 2 & 2 & 2 & 20 & 83 & Baik \\
\hline 7 & Deni Sundari & 3 & 3 & 1 & 2 & 2 & 3 & 2 & 2 & 18 & 75 & Cukup \\
\hline 8 & Dinda Rizki N. & 3 & 2 & 3 & 2 & 3 & 2 & 2 & 3 & 20 & 83 & Baik \\
\hline 9 & Eka Nur Fadila & 3 & 2 & 2 & 2 & 2 & 2 & 2 & 2 & 17 & 71 & Cukup \\
\hline 10 & Feby Ayu W. & 3 & 3 & 2 & 2 & 3 & 3 & 2 & 2 & 20 & 83 & Baik \\
\hline 11 & Gilang Tri W. & 3 & 1 & 3 & 2 & 3 & 2 & 2 & 2 & 18 & 75 & Cukup \\
\hline 12 & Gilang K. & 3 & 2 & 1 & 2 & 1 & 2 & 2 & 1 & 14 & 58 & Cukup \\
\hline 13 & Iftah Yatun & 3 & 2 & 3 & 2 & 3 & 1 & 2 & 3 & 19 & 79 & Cukup \\
\hline 14 & Indah Sasi & 3 & 1 & 3 & 1 & 3 & 3 & 2 & 3 & 19 & 79 & Cukup \\
\hline 15 & Kefin Julianto & 3 & 3 & 3 & 3 & 2 & 1 & 2 & 2 & 19 & 79 & Cukup \\
\hline 16 & Lintang Aji S. & 3 & 2 & 3 & 1 & 2 & 3 & 2 & 3 & 19 & 79 & Cukup \\
\hline 17 & Nimas Ajeng R. & 3 & 3 & 3 & 2 & 2 & 2 & 2 & 2 & 19 & 79 & Cukup \\
\hline 18 & Putri Fernanada & 3 & 3 & 3 & 1 & 3 & 2 & 2 & 3 & 20 & 83 & Baik \\
\hline 19 & Regina C. N. & 3 & 3 & 3 & 3 & 2 & 1 & 1 & 2 & 18 & 75 & Cukup \\
\hline 20 & Rizki Deka P. & 3 & 1 & 3 & 1 & 2 & 3 & 3 & 3 & 19 & 79 & Cukup \\
\hline 21 & Saiful A. & 3 & 3 & 3 & 2 & 1 & 1 & 2 & 2 & 17 & 71 & Cukup \\
\hline 22 & Sefti Nur A. & 2 & 1 & 3 & 2 & 2 & 2 & 2 & 2 & 16 & 67 & Cukup \\
\hline 23 & Suci Ati & 3 & 3 & 2 & 2 & 2 & 2 & 2 & 2 & 18 & 75 & Cukup \\
\hline 24 & Saefa F. & 3 & 3 & 2 & 2 & 2 & 2 & 2 & 1 & 17 & 71 & Cukup \\
\hline 25 & Uswatun Kh. & 3 & 3 & 3 & 2 & 3 & 2 & 2 & 2 & 20 & 83 & Baik \\
\hline 26 & Vania Shafa & 3 & 1 & 3 & 3 & 2 & 3 & 2 & 3 & 20 & 83 & Baik \\
\hline 27 & Wasesa Arya G. & 3 & 3 & 2 & 2 & 3 & 2 & 2 & 3 & 20 & 83 & Baik \\
\hline 28 & Winda & 3 & 3 & 3 & 2 & 3 & 1 & 2 & 3 & 20 & 83 & Baik \\
\hline 29 & *Wulan Lifia & 2 & 2 & 3 & 1 & 2 & 2 & 2 & 2 & 16 & 67 & Cukup \\
\hline 30 & Zarla M. P. & 3 & 1 & 3 & 1 & 3 & 3 & 2 & 2 & 18 & 75 & Cukup \\
\hline 31 & Afnah & 3 & 1 & 3 & 2 & 2 & 2 & 2 & 1 & 16 & 67 & Cukup \\
\hline & Jumlah & 91 & 67 & 81 & 58 & 74 & 64 & 61 & 69 & 565 & 2354 & \\
\hline & Rata2 & 3 & 2 & 3 & 2 & 2 & 2 & 2 & 2 & 18 & 76 & Baik \\
\hline
\end{tabular}

\section{Keterangan:}

1 : Kualitas dan Ruang Lingkup Isi

1a : Kesesuaian pemilihan judul

$1 \mathrm{~b}:$ Kesesuaian isi dengan judul karangan

2 : Organisasi dan Penyajian Isi

2a : Tata tulis dan alur paragraf

$2 \mathrm{~b}$ : Pengmbangan kalimat menjadi paragraf narasi

3 : Gaya dan bentuk bahasa

3 : Penulisan kata pemilihan kata

4 : Mekanik

4a : Penulisan huruf dan kapitalisasi

$4 \mathrm{~b}$ : Penulisan tanda baca

$4 c \quad$ : Kerapihan dan kebersihan 